\title{
An Automated Procedure for the Determination of Total Amino Aclds and its Application to the Analysis of Tobacco*
}

\author{
by P. F. Collins, N. M. Sarji, and J. F. Williams \\ Research Department, Liggett and Myers Incorporated, Durham, N. C., USA
}

\section{INTRODUCTION}

The analysis of tobacco for alpha-amino nitrogen content, which is of considerable value in the evaluation of tobacco quality, is usually carried out by the Van Slyke nitrous acid method (7). This method utilizes the general reaction of primary amines with nitrous acid to produce nitrogen, but the procedure can be made fairly selective for amino nitrogen alpha to a carboxyl group, i. e., alpha-amino acids, by limiting the reaction time to a few minutes as is done in the analysis of tobacco. The procedure is not completely adequate for the accurate determination of total amino acids in tobacco in that proline, a major amino acid of flue-cured tobacco, is not detected, glutamine is detected to the extent of $180 \%$ of the alpha-amino group and ammonia is detected to the extent of $50 \%$. However, when these inadequacies are taken into account, the Van Slyke method was found by Williams and Gerritsen ( 9 ) to yield results for aged and unaged flue-cured tobacco which are reasonably consistent with results for total amino acids determined by liquid chromatography. Further deficiencies of the Van Slyke method as a routine procedure are that it is rather timeconsuming, requiring about $x 5$ minutes for a single determination, considerable technique must be mastered in operating the apparatus, and the procedure does not appear readily amenable to being automated. Thus, it was of considerable interest to develop a procedure which would provide a more accurate estimate of total amino acids in tobacco extracts and which could also be automated to reduce the amount of operator time required.

A number of other procedures have been described for the estimation of total amino acids in plant extracts (4) but, in general, the available procedures appear to lack the desired degree of accuracy. At least one of these, a procedure utilizing the reaction of ninhydrin with amino acids in which the color formation is measured, has been applied to tobacco by Harman et al. (2), but the procedure as described by Spies (3) suffers from interference by ammonia and amines, and has a varying sensitivity for different

- Presented, in gart, at the 27th Tobacco Chemists' Research Conference, Winston-Salem, N. C., USA. October 1973. amino acids with an extremely low sensitivity for proline. Thus, this colorimetric ninhydrin procedure appears capable of providing only a rough estimation of the total amino acid content when applied to a complex mixture such as a tobacco extract. However, in 1941, Van Slyke et al. (8) reported that the ninhydrin reaction could serve as the basis of a highly selective method for alpha-amino acids if the carbon dioxide produced in the reaction was measured instead of the color formation. These authors found that this ninhydrin- $\mathrm{CO}_{2}$ method possessed a constant sensitivity for many alpha-amino acids, including proline, with one mole of $\mathrm{CO}_{2}$ being produced per mole of amino acid. An important exception to this is the case of aspartic acid, wherein two moles of $\mathrm{CO}_{2}$ are evolved per mole. Ammonia and amines do not give rise to $\mathrm{CO}_{2}$ evolution and, therefore, do not interfere.

Of all the methods presently available, it was concluded that this ninhydrin- $\mathrm{CO}_{2}$ method offered the most promise of providing a rapid procedure for the reasonably accurate determination of total amino acids in extracts of tobacco. Therefore, a study was undertaken with the objective of developing an automated procedure based on the ninhydrin- $\mathrm{CO}_{2}$ method and to evaluate it as an alternate to the Van Slyke nitrous acid method for the determination of alpha-amino nitrogen in tobacco. The results of this investigation are described in the following sections.

\section{METHODS AND MATERIALS}

\section{Apparatus}

The Technicon AutoAnalyzer I used in this work consisted of standard modules including a Sampler II with a 30 per hour, $1: 1 \mathrm{cam}$, a Pump I, a $95^{\circ} \mathrm{C}$ heating bath with 1.6 and $2.0 \mathrm{~mm}$ i. d., $40 \mathrm{ft}$. glass coils, and a colorimeter-recorder unit with a $15 \mathrm{~mm}$ flowcell and $540 \mathrm{~nm}$ filters. The manifold is assembled as shown in Figure $I$ using standard AutoAnalyzer fittings except for the B-y separator. This fitting is modified by replacing the supplied metal tube with a section of an 18 gauge syringe needle with squarecut ends and bent in the same manner as the original 
Figure 1. AutoAnalyzer manlfoid for ninhydrin- $\mathrm{CO}_{2}$ procedure.

$\mathrm{ml} \rightarrow \mathrm{min}$

Sample, 30/hr., 1:1

Ninhydrin, $3 \%$

Air, $\mathrm{CO}_{2-f r e e}$

Buffer

Antifoam

Color reagent

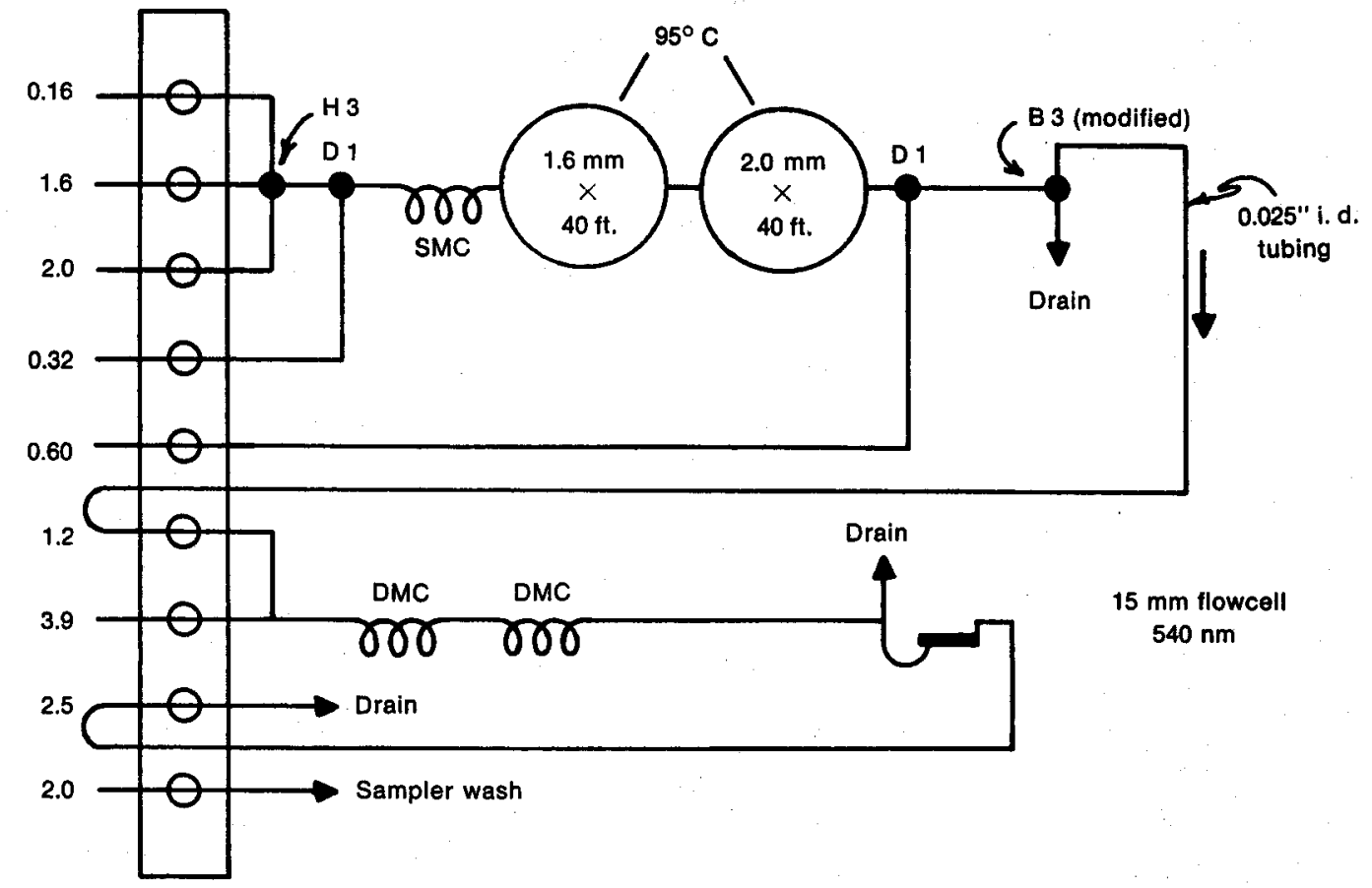

tube. The B-3 fitting is placed as close as practical to the input side of the pump and the $0.025^{\prime \prime}$ i.d. tubing carrying the separated gas stream from the top of the B-3 fitting is connected to a $1.2 \mathrm{ml} / \mathrm{min}$. $\left(0.056^{\prime \prime}\right)$ pump tube which has been cut close to the colored shoulder. To provide $\mathrm{CO}_{2}$-free air for segmenting the sample stream and to protect the color reagent from exposure to atmospheric $\mathrm{CO}_{2}$, the system illustrated in Figure 2 is used ahead of the pump.

Figure 2. System for prevention of contamination by atmospheric $\mathrm{CO}_{2}$.

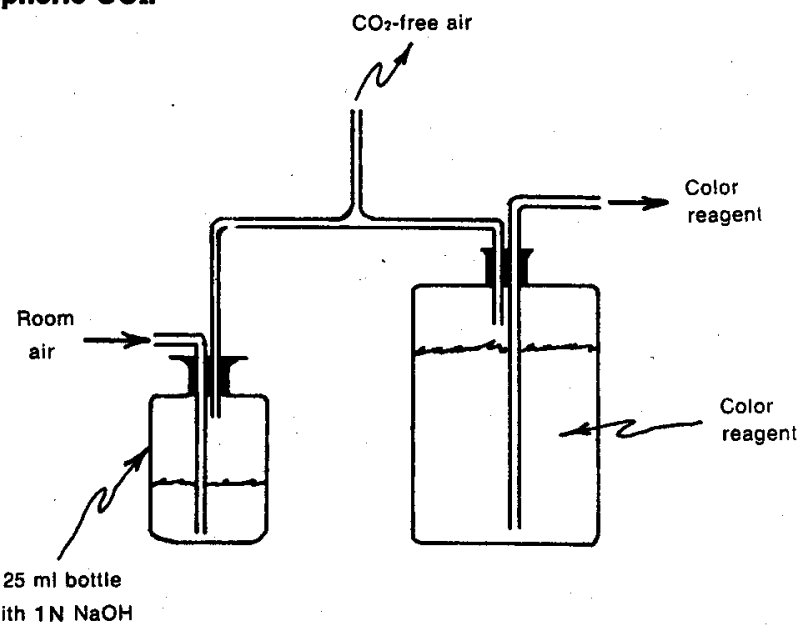

\section{Reagents}

Prepare all solutions using distilled water and reagent grade chemicals except as directed.

1. Ninhydrin Solution, $3 \%$. Dissolve $30 \mathrm{~g}$ of ninhydrin (Pierce reagent grade or equivalent) in about $950 \mathrm{ml}$ of water with gentle warming. Cool, dilute to $1000 \mathrm{ml}$ and add $1.0 \mathrm{ml}$ of Brij-35 (Technicon).
2. Buffer, $p H$ 2.4. Dissolve $6.0 \mathrm{~g}$ of trisodium citrate dihydrate and $56.5 \mathrm{~g}$ of citric acid monohydrate in water to make $500 \mathrm{ml}$ of solution. Verify that the $\mathrm{pH}$ of this solution is $2.4 \pm 0.1$.

3. Buffer, $p H$ 4.7. Dissolve $42.5 \mathrm{~g}$ of trisodium citrate dihydrate and $20 \mathrm{~g}$ of citric acid monohydrate in water to make $500 \mathrm{ml}$ of solution. Verify that the $\mathrm{pH}$ is $4.7 \pm 0.1$.

4. Antifoam Solution. Mix $2.0 \mathrm{ml}$ of Antifoam $\mathrm{H}-10$ Emulsion (Dow-Corning) with $1000 \mathrm{ml}$ of water. Shake each day before use to resuspend the material.

5. Phenolphthalein, $1 \%$. Dissolve $1.00 \mathrm{~g}$ of phenolphthalein in methanol to make $100 \mathrm{ml}$ of solution.

6. Sodium Carbonate-Bicarbonate Solution, $0.33 \mathrm{M}$ in $\mathrm{Na}_{2} \mathrm{CO}_{3}$ and $0.67 \mathrm{M}$ in $\mathrm{NaHCO}_{3}$. Dissolve $17.7 \mathrm{~g}$ of sodium carbonate and $28.0 \mathrm{~g}$ of sodium bicarbonate in water to make $500 \mathrm{ml}$ of solution.

7. Color Reagent. Dilute $4.6 \mathrm{ml}$ of the sodium carbonate-bicarbonate solution (Reagent 6) and $1.6 \mathrm{ml}$ of $1 \%$ phenolphthalein (Reagent 5) to $2000 \mathrm{ml}$ with $\mathrm{CO}_{2}$-free distilled water. Add $1.0 \mathrm{ml}$ of Brij-35. Water sufficiently free of $\mathrm{CO}_{2}$ can be prepared by bubbling a stream of nitrogen through the water for two hours before preparing the solution. The baseline obtained with the color reagent should lie between 22 and $28 \% \mathrm{~T}$, and it may be necessary to adjust the volume of phenolphthalein used to obtain a baseline within this range.

8. Standard Norleucine Solutions. Prepare a $0.0500 \mathrm{M}$ solution by dissolving $3.279 \mathrm{~g}$ of norleucine (Eastman 549) in water to make $500 \mathrm{ml}$ of solution. Prepare additional working standards of $0.0050,0.0100,0.0200$, 0.0300 and $0.0400 \mathrm{M}$ norleucine by dilution with water. 


\section{Analytical Procedure}

Extraction of Tobacco: Place $6.67 \mathrm{~g}$ of the ground tobacco sample in a 250-ml Erlenmeyer flask, add $50.0 \mathrm{ml}$ of water and agitate to thoroughly wet the tobacco. Then add another $50.0 \mathrm{ml}$ of water in such a manner as to wash any tobacco from the walls of the flask down into the mixture. Allow to stand overnight, mix and filter, using a S + S No. 588 folded filter paper.

Analysis of Extracts: With the AutoAnalyzer manifold assembled as shown in Figure 1, pump water through all reagent lines for at least ten minutes. Adjust the colorimeter $\% \mathrm{~T}$ control to obtain a baseline of $100 \% \mathrm{~T}$ with water and then begin pumping reagents. After about 15 minutes, when the system has become stable, start sampling at the rate of 30 per hour with a sample to wash ratio of $1: 1$. Standards are run before and after the sample extracts. At the completion of the run, construct a calibration curve relating molarity to peak height with the data obtained from the standards. Read the molarity for each sample extract and calculate the \% alpha-amino nitrogen:

$\%$ Alpha-amino $\mathrm{N}=$ Molarity $\times 21.00$.

\section{RESULTS AND DISCUSSION}

The initial part of the automated system wherein the sample solution is buffered, mixed with ninhydrin and heated at $95^{\circ} \mathrm{C}$ for about 9 minutes was designed to duplicate as closely as possible the conditions specified by Van Slyke et al. (8) in their manual procedure. It was found necessary to utilize the wetting agent Brij-35 to promote smooth flow through the heating bath, and the addition of the anti-foaming agent to the stream following the heating bath is required for proper operation of the B-3 gas-liquid separator. The final part of the automated system, in which the $\mathrm{CO}_{2}$ produced in the reaction with ninhydrin is measured, is based on Technicon methodology (5). The $\mathrm{CO}_{2}$ is absorbed in a buffered solution of phenolphthalein and the resultant decrease in $\mathrm{pH}$ reduces the color of the solution. A typical chart recording of the standards is shown in Figure 3. Norleucine was chosen as the standard rather than sodium carbonate as used in the Technicon methodology because it was concluded that an amino acid would better serve to calibrate the entire system, and sodium carbonate solutions are prone to contamination by atmospheric $\mathrm{CO}_{2}$.

The ability of the automated procedure to detect various amino acids which commonly occur in tobacco was evaluated by analyzing $0.02 \mathrm{M}$ aqueous solutions prepared from reagent grade amino acids. A $0.02 \mathrm{M}$ solution of sodium carbonate was also analyzed to provide an indication of the completeness of the ninhydrin reaction with the amino acids. The solutions were analyzed using both $\mathrm{pH} 2.4$ and 4.7 buffers inasmuch as Van Slyke reported some difference in response at the two $\mathrm{pH}$ levels. The responses obtained with each solution, relative to norleucine and on a

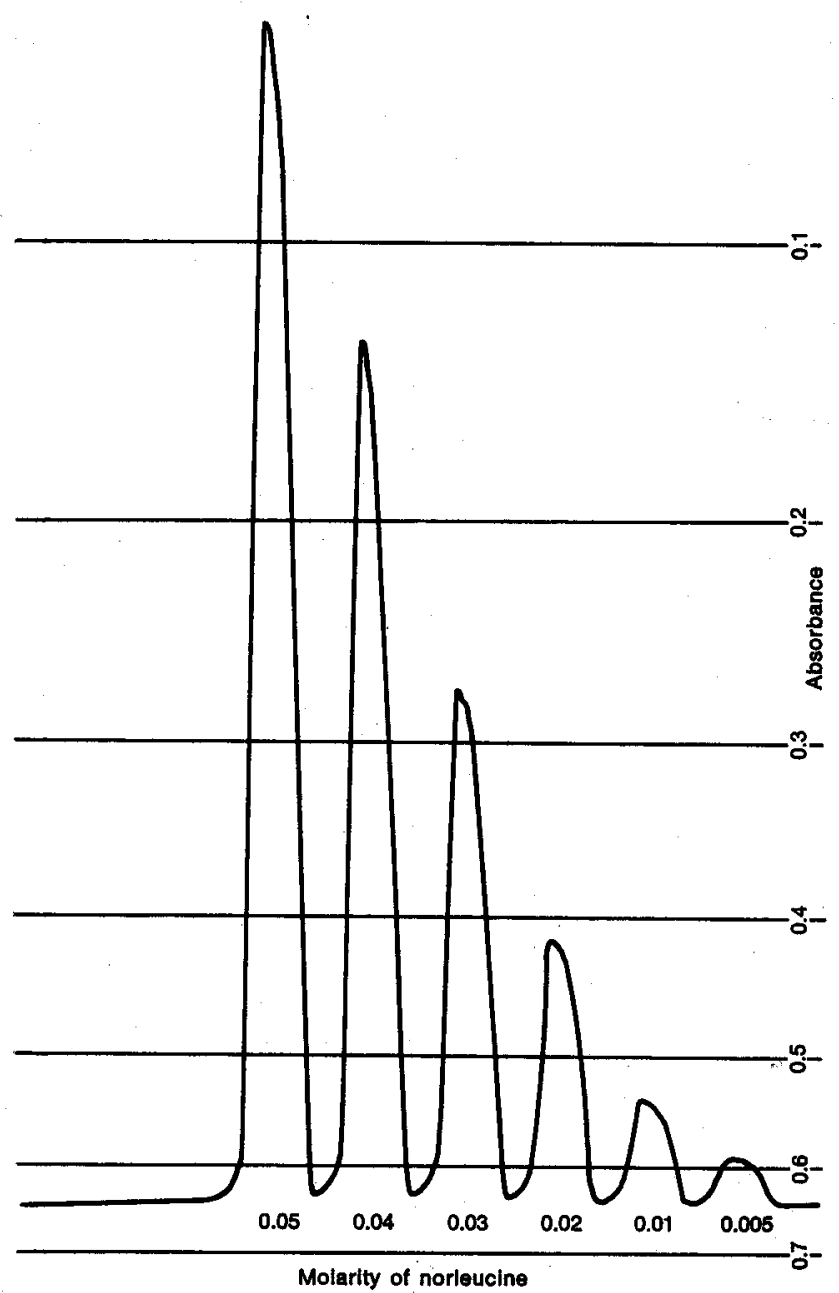

molar basis, are shown in Table 1. It can be seen that the automated procedure detects the various amino acids with fairly constant sensitivity with the exceptions of aspartic acid, lysine (at $\mathrm{pH}_{4.7}$ ) and 4-aminobutyric acid, which is not an alpha-amino acid. These sensitivities are similar to those reported by Van Slyke et al. (8), although they found a somewhat more constant sensitivity for most of the amino acids tested. The results with the sodium carbonate solution indicate that at $\mathrm{pH} 2.4$ the reaction of norleucine is complete to produce one mole of $\mathrm{CO}_{2}$ per mole, whereas a somewhat greater amount of $\mathrm{CO}_{2}$ is evolved at $\mathrm{pH}$ 4.7.

Recovery tests to determine the sensitivity of the automated procedure in the presence of tobacco extracts were carried out with those amino acids typically dominant in flue-cured and burley tobaccos $(I, 9)$. These amino acids were added individually to tobacco extracts at the level of $0.01 \mathrm{M}$ except with aspartic acid where the addition was $0.005 \mathrm{M}$. The results, again relative to the norleucine standards, are compared in Table 2 with those for pure solutions of amino acids. It can be seen that the presence of tobacco ex- 
Table 1. Relative sensitlvity of the automated procedure for amino acids and sodium carbonate.

\begin{tabular}{l|c|c}
\hline \multirow{2}{*}{ Compound } & \multicolumn{2}{|c}{ Relative sensitivity } \\
& $\mathrm{pH} \mathrm{2.4}$ & $\mathrm{pH} \mathrm{4.7}$ \\
\hline Norleucine & 1.00 & 1.00 \\
Alanine & 0.99 & 1.00 \\
4-Aminobutyric acid & 0.00 & 0.06 \\
Asparagine & 1.02 & 1.03 \\
Aspartic acid & 1.88 & 1.86 \\
Glutamic acid & 1.01 & 1.13 \\
Glutamine & 0.95 & 1.00 \\
Glycine & 0.95 & 1.02 \\
Histidine & 1.03 & 1.06 \\
Isoleucine & 1.00 & 1.02 \\
Leucine & 1.01 & 1.02 \\
Lysine & 1.03 & 1.28 \\
Phenylalanine & 1.02 & 1.03 \\
Proline & 1.04 & 1.06 \\
Serine & 1.00 & 1.01 \\
Threonine & 0.98 & 0.93 \\
Sodium carbonate & 0.99 & 0.90 \\
\hline
\end{tabular}

- Relative to norleucine on a molar basis. tracts has little effect on the sensitivity of the procedure for these amino acids.

The possible interference of ammonia and glucose was studied in the presence of flue-cured tobacco extracts as well as in pure solutions. Aqueous solutions of ammonium sulfate $(0.02 \mathrm{M})$ and glucose $(0.08 \mathrm{M})$ gave no response in the procedure. Flue-cured tobacco extracts to which was added, on the tobacco basis, $19.8 \%$ glucose or $0.20 \%$ ammonia gave results for $\%$ alpha-amino nitrogen which were not significantly different from those obtained with the untreated extracts. Therefore, it is concluded that glucose and ammonia do not interfere in the procedure.

To compare the automated ninhydrin- $\mathrm{CO}_{2}$ and $\mathrm{Van}$ Slyke nitrous acid procedures for the determination of alpha-amino nitrogen in tobacco, samples of fluecured and burley strip from the 1972 crop were analyzed. Duplicate extracts of each tobacco sample were prepared and a single analysis of each extract was made by each procedure. A total of 395 samples of flue-cured and 82 samples of burley tobacco were analyzed with results as summarized in Table 3 for flue-cured

Table 2. Relative sensitivity of the automated procedure for various amino acids added to tobacco extracts.

\begin{tabular}{|c|c|c|c|c|c|c|}
\hline \multirow[b]{2}{*}{ Amino acid added } & \multicolumn{6}{|c|}{ Relative response for added amino acid" } \\
\hline & $\mathrm{H}_{2} \mathrm{O}$ & $\begin{array}{c}\mathrm{pH} 2.4 \\
\text { Flue-cured } \\
\text { tobacco } \\
\text { extract } \\
\end{array}$ & $\begin{array}{c}\text { Burley tobacco } \\
\text { extract }\end{array}$ & $\mathrm{H}_{2} \mathrm{O}$ & $\begin{array}{c}\mathrm{pH} 4.7 \\
\text { Flue-cured } \\
\text { tobacco } \\
\text { extract } \\
\end{array}$ & $\begin{array}{c}\text { Burley tobacco } \\
\text { extract }\end{array}$ \\
\hline Proline & 1.04 & 1.02 & 1.07 & 1.06 & 1.02 & 1.08 \\
\hline Glutamic acid & 1.01 & 1.00 & 1.04 & 1.13 & 1.13 & 1.18 \\
\hline Aspartic acid & 1.88 & 1.86 & 1.92 & 1.86 & 1.72 & 1.94 \\
\hline Asparagine & 1.02 & 0.99 & 1.04 & 1.03 & 0.98 & 0.98 \\
\hline Glutamine & 0.95 & 0.92 & 1.02 & 1.00 & 1.01 & 1.02 \\
\hline
\end{tabular}

* Relative to the norleucine in water standards.

Table 3. Summary of results for alpha-amino nitrogen in flue-cured tobacco. (Number of samples - 395)

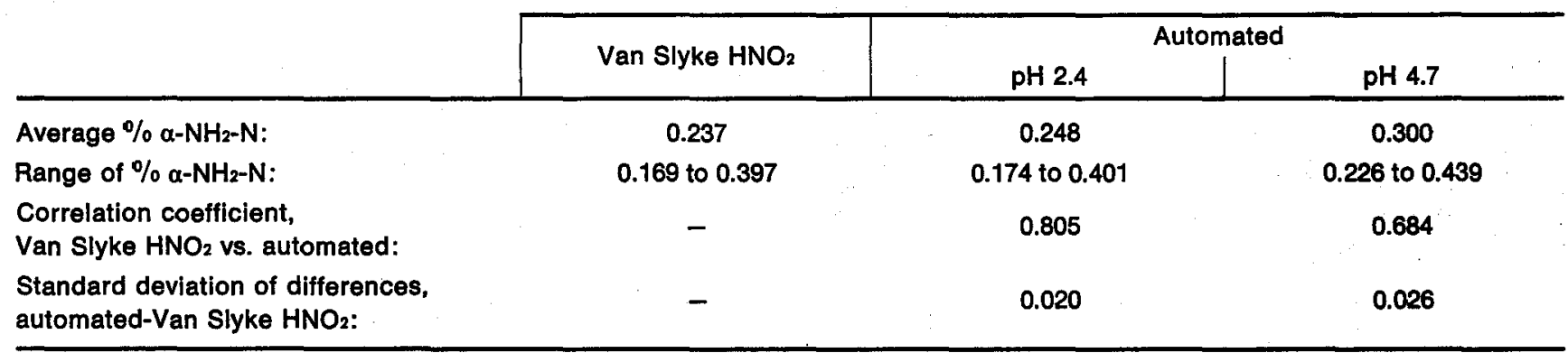

Table 4. Summary of results for alpha-amino nitrogen in burley tobacco. (Number of samples - 82)

\begin{tabular}{|c|c|c|c|}
\hline & Van Slyke $\mathrm{HNO}_{2}$ & pH 2.4 & pH 4.7 \\
\hline Average $\% \alpha-\mathrm{NH}_{2}-\mathrm{N}$ : & 0.555 & 0.578 & 0.569 \\
\hline Range of $\% \alpha-\mathrm{NH}_{2}-\mathrm{N}$ : & 0.356 to 0.763 & 0.447 to 0.774 & 0.437 to 0.746 \\
\hline $\begin{array}{l}\text { Correlation coefficient, } \\
\text { Van Slyke } \mathrm{HNO}_{2} \text { vs. automated: }\end{array}$ & - & 0.912 & 0.942 \\
\hline $\begin{array}{l}\text { Standard deviation of differences, } \\
\text { automated-Van Slyke } \mathrm{HNO}_{2} \text { : }\end{array}$ & - & 0.041 & 0.035 \\
\hline
\end{tabular}


and in Table 4 for the burley samples. With the fluecured samples, quite good agreement was found between the overall average of $\%$ alpha-amino nitrogen by the nitrous acid procedure and the automated procedure at $\mathrm{pH}$ 2.4. The average by the automated procedure is $0.011 \%$ higher and the differences between procedures for the individual samples have a standard deviation of $0.020 \%$ alpha-amino nitrogen. Therefore, if these results are assumed to be generally typical for flue-cured tobacco and, further, that the differences for individual samples are normally distributed as they appear to be, then for $95 \%$ of flue-cured samples, the automated results would be expected to differ from the value by the nitrous acid procedure by no more than $0.011 \pm 0.040 \%$ alpha-amino nitrogen. Simi-

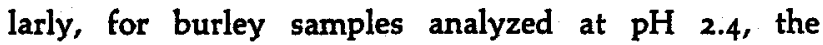
automated result for $95 \%$ of the samples should differ by no more than $0.023 \pm 0.081 \%$.

The $\mathrm{pH}$ at which the ninhydrin reaction is conducted is seen to have little effect on the results for burley tobacco, but with flue-cured, the average at $\mathrm{pH} 4.7$ is about $20 \%$ higher than at the lower $\mathrm{pH}$. As reported by Tomita et al. (6), part of the amino acids in fluecured and sun-cured tobaccos appears to exist in combination with sugar and this suggested that the higher results at $\mathrm{pH} 4.7$ might be due to greater detection of amino acid-sugar complexes at the higher $\mathrm{pH}$. While this has not yet been investigated to a great extent, experiments with a $1: 1$ proline-glucose compound indicated that this compound is detected to a much greater degree at the higher $\mathrm{pH}$. At $\mathrm{pH} 2.4$, only 0.05 mole of $\mathrm{CO}_{2}$ is liberated per mole of compound while at $\mathrm{pH} 4.7$ the evolution of $\mathrm{CO}_{2}$ increases to 0.72 mole per mole. If the amino acid-sugar compounds in flue-cured tobacco behave similarly, this could well explain the higher results at $\mathrm{pH} 4.7$.

The precision of the automated procedure for the analysis of tobacco extracts was evaluated by repeated analysis of a sample of cigarette filler tobacco which was utilized as a control sample during the analysis of the flue-cured and burley samples. This sample was analyzed in duplicate on each of 31 days with results as shown in Table 5. A further estimate of the precision of the procedure was obtained by analyzing 22 burley samples in duplicate on each of two days. The relative standard deviations found for the average of duplicates on the same day were $1.5 \%$ at $\mathrm{pH} 2.4$ and $2.8 \%$ at $\mathrm{pH} 4.7$, in good agreement with the precision estimates obtained with the cigarette filler.

Table 5. Precision of the automated procedure for alphaamino nitrogen In a clgarette filler tobacco.

\begin{tabular}{lcc}
\cline { 2 - 3 } & $\mathrm{pH} 2.4$ & $\mathrm{pH} 4.7$ \\
\hline No. of duplicate determinations & 31 & 31 \\
Average $\% \alpha-\mathrm{NH}_{2}-\mathrm{N}$ & 0.228 & 0.247 \\
Standard deviation, $\% \alpha-\mathrm{NH}_{2}-\mathrm{N}^{*}$ & 0.0039 & 0.0059 \\
Relative standard deviation, $\%$ & 1.7 & 2.4 \\
\hline
\end{tabular}

- For the average of duplicate determinations on a single day.
In an attempt to assess the accuracy of the automated procedure for the determination of total alpha-amino acids in tobacco, 1.2 samples of tobacco were analyzed for individual amino acids by ion-exchange chromatography as described by Williams and Gerritsen (9), as well as for alpha-amino nitrogen by the automated and nitrous acid procedures. The 16 alpha-amino acids determined chromatographically were alanine, arginine, asparagine, aspartic acid, glutamic acid, glutamine, glycine, histidine, isoleucine, leucine, lysine, phenylalanine, proline, serine, threonine, and tyrosine. For each sample, the results for these amino acids were used to calculate a value for total alpha-amino nitrogen. These calculated values have some uncertainty associated with them because the determination of threonine, serine, asparagine and glutamine involves the use of an acidhydrolyzed extract and it is possible that a part of these amino acids found resulted from hydrolysis of peptides and amino acid-sugar complexes. These calculated values and the results by the alpha-amino nitrogen procedures are compared in Table 6. From an inspection of these data, it is immediately obvious that neither procedure gives results in consistently good

Table 6. Comparison of alpha-amino nitrogen found in tobacco by various methods.

\begin{tabular}{|c|c|c|c|c|}
\hline \multirow{2}{*}{ Tobacco type } & \multicolumn{4}{|c|}{$\%$ Alpha-amino nitrogen found ${ }^{*}$} \\
\hline & AAC & VS & $\begin{array}{c}\mathrm{AA}, \\
\mathrm{pH} 2.4\end{array}$ & $\begin{array}{c}\mathrm{AA}, \\
\mathrm{pH} 4.7\end{array}$ \\
\hline Flue-cured & 0.285 & 0.323 & 0.234 & 0.277 \\
\hline Flue-cured & 0.226 & 0.224 & 0.179 & 0.261 \\
\hline Flue-cured & 0.230 & 0.234 & 0.188 & 0.237 \\
\hline Flue-cured & 0.265 & 0.275 & 0.216 & 0.298 \\
\hline Flue-cured & 0.087 & 0.109 & 0.069 & 0.109 \\
\hline Flue-cured & 0.164 & 0.148 & 0.165 & 0.214 \\
\hline Cigarette filler & 0.203 & 0.198 & 0.180 & 0.248 \\
\hline Cigarette filler & 0.166 & 0.168 & 0.135 & 0.204 \\
\hline Cigarette filler & 0.175 & 0.145 & 0.134 & 0.204 \\
\hline Burley & 0.256 & 0.369 & 0.338 & 0.330 \\
\hline Burley & 0.258 & 0.354 & 0.417 & 0.420 \\
\hline Turkish & 0.333 & 0.200 & 0.273 & 0.303 \\
\hline Average & 0.221 & 0.229 & 0.211 & 0.259 \\
\hline
\end{tabular}

- Subheadings represent methods as follows: AAC, amino acid chromatography; VS, Van Slyke HNO;; AA, automated.

Table 7. Linear regression analysis of alpha-amino nitrogen results.

\begin{tabular}{l|c|c|c}
\hline Procedure* & $\begin{array}{c}\text { Correlation } \\
\text { coefficient }\end{array}$ & Intercept & Slope \\
\hline Van Slyke HNO2 & 0.692 & 0.098 & 0.537 \\
Automated, pH 2.4 & 0.728 & 0.114 & 0.505 \\
Automated, pH 4.7 & 0.791 & 0.046 & 0.674 \\
\hline
\end{tabular}

- In all cases, the results by chromatography are used as the dependent variable. 
agreement with the chromatographic values. To evaluate these data, linear regression techniques were applied with results as shown in Table 7 . It was found that the automated procedure, especially at $\mathrm{pH} 4.7$, yields results that are more highly correlated with chromatographic values than does the nitrous acid procedure.

The lack of agreement between the automated results and dromatographic values can be partially accounted for, in the case of the burley samples, by the anomalous sensitivity of the automated procedure for aspartic acid. For the two burley samples dromatographically analyzed in this work, 20 to $25 \%$ of the total alpha-amino acid was aspartic acid and, based on the values reported by de la Burde et al. (1), aspartic acid can represent more than one-third of the total amino acids in burley. In the case of flue-cured tobacco, the error due to aspartic acid is considerably lower as this acid generally represents less than $5 \%$ of the total amino acids. The aforementioned uncertainties associated with the chromatographic amino acid determination may also contribute to part of the differences found.

Although the automated ninhydrin- $\mathrm{CO}_{2}$ procedure has not been demonstrated capable of accurately determining the total amino acids in tobacco extracts, it still appears potentially useful as a routine method for the analysis of tobacco. Samples can be analyzed at a faster rate and with considerably less operator attention than is required with the nitrous acid procedure. Further, since the procedure has been found to yield results for alpha-amino nitrogen which are more highly correlated with dromatographically determined values than are results by the nitrous acid procedure, it may possibly provide a more meaningful measurement for the evaluation of tobacco insofar as the total alphaamino acid content is a determining factor in the quality of tobacco.

\section{SUMMARY}

An automated procedure for the determination of total alpha-amino acids in aqueous solution has been developed which utilizes the Technicon AutoAnalyzer I. The procedure is based in part on a manual method proposed by Van Slyke wherein the $\mathrm{CO}_{2}$ produced in the reaction of amino acids with ninhydrin serves as a measure of the alpha-amino acid concentration. Evaluation of the procedure for the determination of alpha-amino nitrogen in extracts of flue-cured and burley tobaccos indicates that adequately precise results are obtained which show a fairly high correlation $\left(\mathrm{r}=0.8\right.$ to 0.9 ) with results by the classical $V_{a n}$ Slyke nitrous acid procedure. The relation of the amino acid content of a variety of tobacco types, as determined by ion-exchange chromatography, to alpha-amino nitrogen results by the automated and nitrous acid procedures has been investigated. While the results indicate that neither procedure provides consistently accurate values for total amino acids in tobacco, it was found that the results by the automated procedure show a somewhat higher degree of correlation with total alpha-amino acids. It is therefore concluded that the automated procedure may be potentially useful in the evaluation of tobacco.

\section{ZUSAMMENFASSUNG}

Zur Bestimmung der gesamten Alpha-Aminosäuren in wässeriger Lösung wurde unter Einsatz des Technicon AutoAnalyzer I eine automatische Methode entwidkelt. Sie basiert teilweise auf einem von Van Slyke vorgeschlagenen manuellen Verfahren, in dem das Kohlendioxid, das sich bei der Reaktion der Aminosäuren mit Ninhydrin bildet, als Maßstab für die Konzentration an Alpha-Aminosäuren dient. Die Anwendung der Methode bei der Bestimmung von Alpha-Aminostickstoff in Extrakten von Virginia- und Burley-Tabaken zeigt, daß hinreichend genaue Ergebnisse erzielt werden können, die eine redht gute Korrelation $(r=0,8-0,9)$ zu Werten aufweisen, die man durch das klassische Verfahren von Van Slyke mit Salpetersäure erhält. Bei einer Reihe von Tabaktypen wurde die Relation untersucht, die sich aus den mittels Ionenaustaushdhromatographie erhaltenen Werten einerseits und denen der automatischen Methode sowie des Salpetersäureverfahrens andererseits ergab. Während die Resultate zeigten, daß keines der Verfahren durchweg genaue Werte für den Gesamtgehalt an Aminosäuren im Tabak erbringt, weisen die Ergebnisse des automatischen Verfahrens dennodh eine etwas höhere Korrelation zu den Werten der gesamten Alpha-Aminosäuren auf. Die Autoren kommen daher zu dem Schluß, daß die automatische Methode bei der Untersuchung von Tabak potentiell nützlich sein kann.

\section{RESUME}

On a développé une méthode automatisée, utilisant le Technicon AutoAnalyzer I, pour la détermination des alpha-aminoacides totaux en solution aqueuse. La méthode est basée en partie sur une méthode manuelle proposée par Van Slyke, où le $\mathrm{CO}_{2}$ produit par la réaction de la ninhydrine avec les aminoacides sert de mesure de la concentration en alpha-aminoacides. On a appliqué cette méthode à la détermination de l'alphaaminoazote dans des extraits de tabac "flue-cured" et burley. Les résultats obtenus sont suffisamment précis, et leur degré de corrélation avec les résultats obtenus par la méthode classique de Van Slyke (acide nitreux) est relativement élevé $(r=0,8$ à 0,9$)$. Par chromatographie par échange d'ions, on a déterminé la teneur en aminoacides de plusieurs types de tabac. Ces résultats ont été comparés à la teneur en alpha-aminoazote obtenue par la méthode automatisée et par la méthode acides nitreux. Aucune de ces deux dernières méthodes ne donnent des valeurs précises et sûres quant aux acides aminés totaux dans le tabac, mais il semblerait $\mathrm{y}$ avoir un degré de corrélation un peu plus grand dans la méthode automatisée. Il est donc possible que cette méthode pourrait être utile à l'avenir pour l'évaluation du tabac. 


\section{REFERENCES}

1. De la Burde; R., E. H. Poindexter, Jr., and J. P. Bell: The distribution of amino acids in tobaccos from different stalk positions; TobaccoSci. 9(1965) 26-32.

2. Harman, G. E., G. V. Gooding, Jr., and T. T. Hebert: Effect of tobacco mosaic virus infection on some chemical constituents of flue-cured tobacco; Tobacco Sci. 14 (1970) 138-140.

3. Spies, Joseph R.: Colorimetric procedures for amino acids, In: Colowid, S. P., and N. O. Kaplan, Eds., "Methods in enzymology", Vol. 3; Academic Press, 1957, pp. 467-477.

4. Synge, R. L. M.: Peptides and free amino acids, In: Paech, K., and M. V. Tracey, Eds., "Modern methods of plant analysis", Vol. 4; Springer-Verlag, 1955, pp. 13-14.

5. Technicon Method Publication N-8b, The Technicon Corporation, Tarrytown, N. Y., 10591.
6. Tomita, Hideo, M. Noguchi, and E. Tamaki: Chemical studies on ninhydrin-positive compounds in tobacco leaves, Part IlI: Further isolation of some amino acid-sugar compounds; Agr. Biol. Chem. 29 (1965) 959-961.

7. Van Slyke, Donald D.: The quantitative determination of aliphatic amino groups; J. Biol. Chem. 12 (1912) 275-284.

8. Van Slyke, Donald D., R. T. Dillon, D. A. MacFadyen and P. Hamilton: Gasometric determination of carboxyl groups in free amino acids; J. Biol. Chem. 141 (1941) 627-669.

9. Williams, J. F., and B. H. Gerritsen: Changes in amino acid content of flue-cured tobacco during naţural aging; Tobacco Sci. 12 (1968) 243-247.

The authors' address:

Liggett and Myers Inc., Research Department, Durham, N. C., 27702, USA. 